\title{
Nové pohledy na léčbu arytmií
}

Sympozium společnosti PRO.MED.CS Praha a.s., které proběhlo v rámci XXIX. výročního sjezdu České kardiologické společnosti 13. 5. 2021, bylo zaměřené na moderní techniky v léčbě srdečních arytmií. Prof. Kautzner se ve své přednášce věnoval př́nosu ablace fibrilace síní (FS), významu udržení sinusového rytmu pro prognózu nemocných a novým technologiím, které umožní provedení výkonu u většího počtu pacientů s větší účinností. MUDr. Hašková připomněla a na výsledcích klinických hodnocení doložila, že kompenzace ovlivnitelných rizikových faktorů, jako je obezita, nedostatek pohybové aktivity, konzumace alkoholu, kouření, může snižit výskyt FS. MUDr. Čihák prezentoval data, která ukazují př́nos ablace FS u pacientů se srdečním selháním vzniklým $v$ důsledku FS a u nově zjištěné FS u pacientů se srdeční resynchronizační léčbou (CRT). Vysvětlil také př́nos ablace AV junkce u nemocných s CRT stimulací a FS, kdy není zvažována selektivní ablace pro FS. Doc. Peichl se věnoval řešení arytmické bouře. Ukázal, že farmakoterapeuticky je nejvhodnější kombinace neselektivního $\beta$-blokátoru a amiodaronu, u primárních arytmických syndromů pak specifická antiarytmická léčba. Pro akutní potlačení bouře lze využít sedaci nebo opich ganglion stellatum. Účinnou metodou pro prevenci recidiv komorových arytmií je včasná katetrizační ablace. Doc. Wichterle popsal indikace a provedení kardioneuroablace jako perspektivní léčebné metody v př́padě reflexních kardioinhibičních synkop a symptomatické bradyarytmie. Jde o bezpečnou a vysoce účinnou metodu, která představuje alternativu implantace pacemakeru. Na sympoziu také představil doc. Kettner 3. přepracované a dopIněné vydání knihy Akutní kardiologie (Grada), kterou připravil kolektiv autorů z IKEM a která je určena lékařům a zdravotním sestrám na koronárních jednotkách, JIP, odděleních urgentního přijmu i interních odděleních.

\section{Vyplatí se léčit fibrilaci síní? \\ prof. MUDr. Josef Kautzner, CSc., FESC \\ (Klinika kardiologie IKEM, Praha)}

Antiarytmika jsou stále léčbou 1. volby pro většinu nemocných s fibrilací síní (FS). Analýza studií s jednotlivými přípravky ale ukázala, že sinusový rytmus se u většiny antiarytmik daří udržet u méně než $50 \%$ pacientů a navíc je jejich podávání provázeno nežádoucími účinky (1). Základem katetrizační léčby FS je izolace plicních žil doplněná o další léze v levé síni. Používá se řada technologií. Roční sledování pacientů z evropského registru EHRA z různých pracovišt ukázalo, že ablace FS je úspěšná z hlediska udržení sinusového rytmu zhruba v 70\% případů s prijiatelnou bezpečností (2).

Metaanalýza historických studií s antiarytmiky nezjistila prognostický prínos kontroly srdečního rytmu v porovnání s kontrolou srdeční frekvence (3). Studie ale měly řadu nedostatků, např. vysazování antikoagulancií při dosažení sinusového rytmu nebo zařazení pouze pacientů, kteří FS tolerují. Naopak novější studie CASTLE AF zahrnující 3013 pacientů se symptomatickou fibrilací síní, srdečním selháním a implantací defibrilátoru (ICD/CRT-D) ukázala významný přínos ablace FS v porovnání s konvenční léčbou z hlediska mortality na srdeční selhání nebo hospitalizace pro srdeční selhání a také z hlediska celkové mortality (4). Studie CABANA, která sledovala rizikové pacienty s nově zjištěnou FS, ukázala, že iniciální ablace FS je u dosud neléčených pacientů s FS spojena s nižším rizikem první recidivy než farmakoterapie a také s nižší mortalitou (5). Nedávno publikovaná studie EAST-AFNET 4 prokázala přínos intenzivní časné kontroly rytmu u pacientů s nedávno zjištěnou FS a rizikem kardiovaskulární (KV) příhody v porovnání s obvyklou péčí (obr. 1) (6). Primární sledovaný
Obr. 1. Snižení výskytu složeného parametru (úmrtíz KV príčin, CMP, hospitalizace pro srdeční selhání a hospitalizace pro AKS) při intenzivní časné kontrole rytmu v porovnánís obvyklou péčí u pacientů s nedávno zjištěnou FS a rizikem KV príhody ve studii EAST-AFNET 4 (6)

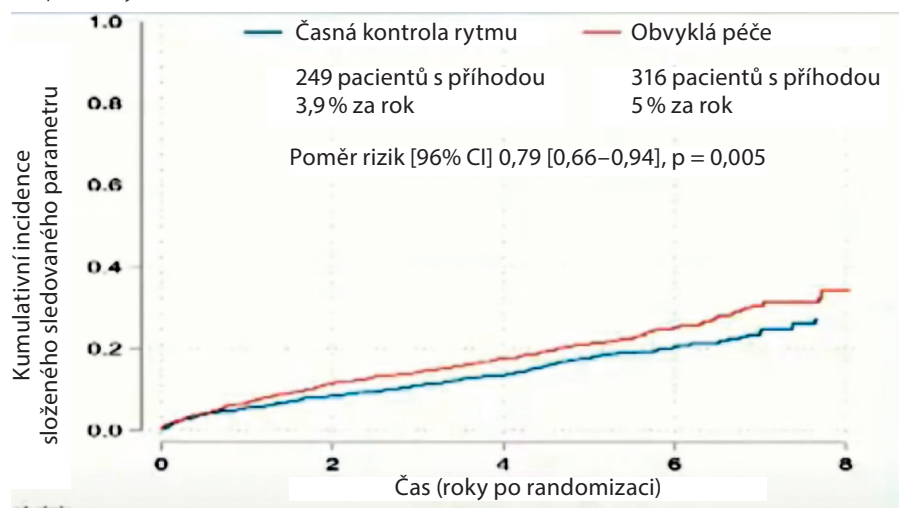

parametr zahrnoval úmrtí z KV příčin, cévní mozkové príhody (CMP), hospitalizaci pro srdeční selhání a hospitalizaci pro akutní koronární syndrom (AKS). Př́nos intenzivní léčby byl dán především poklesem KV mortality a rizika CMP a byl dosažen i při ne př́liš vysokém podílu pacientů s katetrizační ablací.

Tyto př́iznivé výsledky otevírají otázku, zda bude v budoucnu možné provádět katetrizační ablaci u velkého počtu pacientů s FS, a zlepšit tak u nich výsledky léčby a kvalitu života. Jednou z možných technik, které Ize ke katetrizační ablaci FS využít, je tzv. PEFA (PFA), neboli energie pulzního pole či elektroporace, která využívá krátké pulzy stejnosměrného proudu k destabilizaci buněčných membrán. V membránách vznikají póry a zasažené buňky poté zanikají, aniž je aplikována termální energie. Obtížnější je titrace správného tvaru pulzu. Výhodou je ovšem vyšší cit- 


\section{NOVINKY V KARDIOLOGII}

NOVÉ POHLEDY NA LÉČBU ARYTMIÍ

livost kardiomyocytů na elektroporaci v porovnání s okolními buňkami stromatu, vaziva nebo nervovými buňkami a vyplývající minimální riziko poškození okolních struktur, např. jícnu, plic či n. phrenicus. Př́kladem prístroje pro elektroporaci může být mapovací a ablační systém AFFERA, který má řiditelný elektrodový katétr, aplikuje radiofrekvenční proud (RF) i pulzní pole (PF) přes $9 \mathrm{~mm}$ hrot s mřižkovou elektrodou, disponuje 9 teplotními senzory a minielektrodami, a dovoluje tak mapování o vysoké denzitě a aplikaci energie s kontrolou teploty. Nedávno byla publikována první studie provedená u lidí, porovnávající ablaci FS pomocí RF/PF, PF/PF a samotné RF. Ukázala výrazné zkrácení doby skiaskopie i doby ablace v kohortě pacientů s PF/PF a vysokou bezpečnost techniky (7).

Tyto nové techniky jsou přislibem možnosti léčby velkého množství pacientů s FS pomocí katetrizační ablace v krátkém čase. Další studie provedená převážně v pražské Nemocnici Na Homolce hodnotila vý-

\section{LITERATURA}

1. Savelieva I, Kourliouros A, Camm J. Primary and secondary prevention of atrial fibrillation with statins and polyunsaturated fatty acids: review of evidence and clinical relevance. Naunyn Schmiedebergs Arch Pharmacol 2010; 381(3): 1-13.

2. Arbelo E, Brugada J, Blomström-Lundqvist C, Laroche C, Kautzner J, Pokushalov E, Raatikainen P, Efremidis M, Hindricks G, Barrera A, Maggioni A, Tavazzi L, Dagres N; on the behalf of the ESC-EHRA Atrial Fibrillation Ablation Long-term Registry Investigators. Contemporary management of patients undergoing atrial fibrillation ablation: in-hospital and 1-year foIlow-up findings from the ESC-EHRA atrial fibrillation ablation long-term registry. Eur Heart J 2017; 38(17): 1303-1316.

3. Caldeira D, David C, Sampaio C. Rate versus rhythm control in atrial fibrillation and clinical outcomes: updated systematic review and meta-analysis of randomized controlled trials. Arch Cardiovasc Dis. 2012; 105(4): 226-238

4. Marrouche NF, Brachmann J, Andresen D, Siebels J, Boersma L, Jordaens L, Merkely B, Pokushalov E, Sanders P, Proff J, Schunkert H, Christ H, Vogt J, Bänsch D; CASTLE-AF Investigators. Catheter Ablation for Atrial Fibrillation with Heart Failure. N Engl J Med 2018; 378(5): 417-427.

5. Packer DL, Mark DB, Robb RA, Monahan KH, Bahnson TD, Poole JE, Noseworthy PA Rosenberg YD, Jeffries N, Mitchell LB, Flaker GC, Pokushalov E, Romanov A, Bunch TJ, Noelke G, Ardashev A, Revishvili A, Wilber DJ, Cappato R, Kuck KH, Hindricks G, Davies DW, Kowey PR, Naccarelli GV, Reiffel JA, Piccini JP, Silverstein AP, Al-Khalidi HR, Lee KL; CABANA Investigators. Effect of Catheter Ablation vs Antiarrhythmic Drug Therapy on Mortality, Stroke, Bleeding, and Cardiac Arrest Among Patients With Atrial Fibrillation: The CABANA Randomized Clinical Trial. JAMA 2019; 321(13): 1261-1274.

6. Kirchhof P, Camm AJ, Goette A, Brandes A, Eckardt L, Elvan A, Fetsch T, van Gelder IC, Haase D, Haegeli LM, Hamann F, Heidbüchel H, Hindricks G, Kautzner J, Kuck KH, Mont L, Ng GA, Rekosz J, Schoen N, Schotten U, Suling A, Taggeselle J, Themistoclakis S, Vettorazzi E, Vardas P, Wegscheider K, Willems S, Crijns HJGM, Breithardt G; EAST-AFNET 4 Trial Investigators. Early Rhythm-Control Therapy in Patients with Atrial Fibrillation. N Engl J Med 2020; 383(14): 1305-1316. 7. Reddy VY, Anter E, Rackauskas G, PeichI P, Koruth JS, Petru J, Funasako M, Minami K, Natale A, Jais P, Nakagawa H, Marinskis G, Aidietis A, Kautzner J, Neuzil P. Lattice-Tip Focal Ablation Catheter That Toggles Between Radiofrequency and Pulsed Field Energy to Treat Atrial Fibrillation: A First-in-Human Trial. Circ Arrhythm Electrophysiol 2020; 13(6): e008718.

8. Reddy VY, Neuzil P, Koruth JS, Petru J, Funosako M, Cochet H, Sediva L, Chovanec M, Dukkipati SR, Jais P. Pulsed Field Ablation for Pulmonary Vein Isolation in Atrial Fibrillation. Am Coll Cardiol 2019; 74(3): 315-326.

\section{Mohou změny životního stylu snížit riziko recidivy fibrilace síní? MUDr. Jana Hašková (Klinika kardiologie IKEM, Praha)}

Samostatná (lone) fibrilace síní (FS) bez dalších komorbidit a rizikových faktorů se týká minimálního počtu pacientů. Podle analýzy 15400 pacientů s FS z registru RELY mělo lone FS $5 \%$ pacientů, ovšem po podrobnějši analýze byly u $86 \%$ z nich zjištěny subklinické rizikové faktory. Skutečná lone FS se týkala pouze 17 (0,1%) pacientů (9). sledky izolace plicních žil ablací pulzním polem metodou „single shot" se zavedením katétru ve tvaru květiny do ústí plicní žily a aplikací několika pulzů energie. Poté, co byla metoda vyvinuta z monofázické do bifázické konfigurace, bylo po 3 měsících u posledních 14 pacientů dosaženo 100\% trvalé izolace plicních žil při trvání výkonu 92 +/-27 min včetně 20 min pro remapování. Nedošlo k žádné stenóze plicních žil ani poraněníjícnu a po 6 měsících bylo bez FS $90 \%$ pacientů a po 12 měsících $87 \%$ pacientů (8).

\section{Závěr}

Farmakoterapie a katetrizační ablace mají velký potenciál udržet sinusový rytmus a zlepšit kvalitu života pacientů s FS. Udržení sinusového rytmu je pritom prokazatelně spojeno se zlepšením prognózy nemocných. Nové technologie ablace, jako je ireverzibilní elektroporace, umožní provedení výkonu u většího počtu pacientů s větší účinností.

FS je multifaktoriální onemocnění s velkým počtem rizikových faktorů zahrnujících věk, genetiku, etnickou skupinu, mužské pohlaví, kouření, konzumaci alkoholu, obezitu, fyzickou inaktivitu, prítomnost onemocnění, jako je CHOPN, diabetes, ICHS, dyslipidemie, arteriální hypertenze, srdeční selhání, chronické onemocnění ledvin, obstrukční spánková apnoe, srdeční selhání, chlopenní vady a také akutní onemocnění a chirurgické výkony.

Bylo doloženo, že riziko 1. epizody FS je významně vyšší u osob s obezitou v porovnání s jedinci s nadváhou nebo zdravou tělesnou hmotností. U obézních pacientů, kterým se podařilo snižit tělesnou hmotnost, byl pokles BMI o 1 kg/m² spojen se snížením rizika vzniku FS o $7 \%$ (9). Česká práce ukázala, že obézní pacienti s FS mají častěji hypertenzi v levé síni a horší výsledky katetrizační ablace v podobě častějších recidiv (10). Studie LEGACY s pacienty s FS a BMI $>27 \mathrm{~kg} / \mathrm{m}^{2}$ doložila, že jedinci s redukcí tělesné hmotnosti o > 10\% dosahují častěji sinusového rytmu a méně často potřebují antiarytmika než nemocní, kterým se podaři snízit hmotnost pouze o 3-9\% nebo o méně než 3\% (11).

Obr. 2. Snižení tělesné hmotnosti u pacientů s BMI $>27 \mathrm{~m} / \mathrm{kg}^{2}$ o $>10 \%$ je spojeno s významným poklesem rizika FS (11)

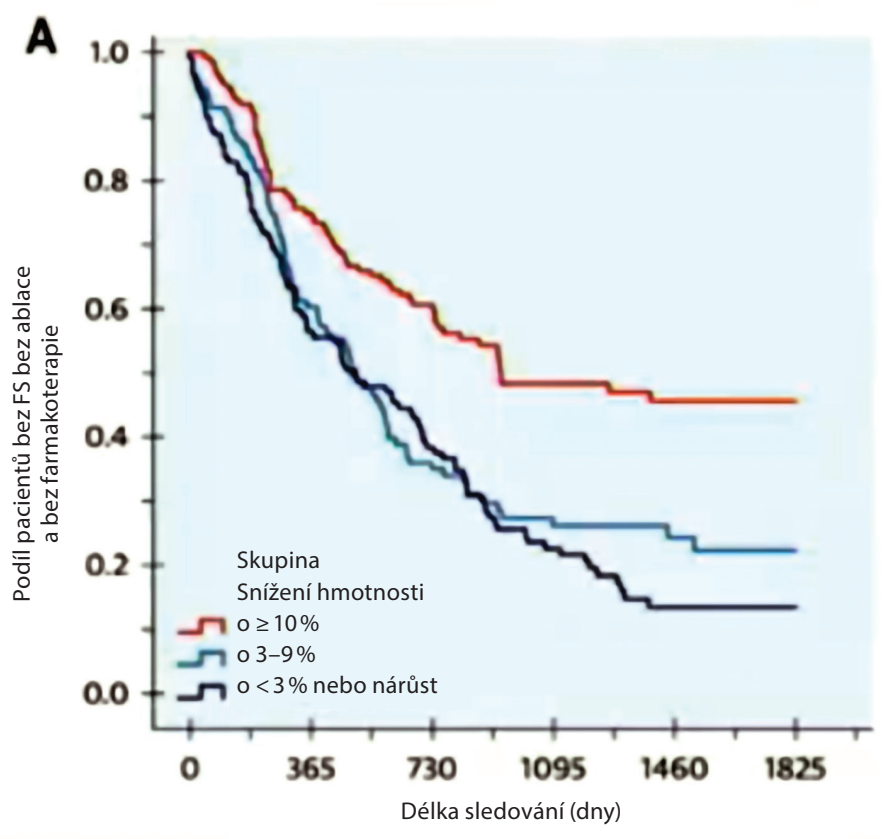


Obr. 3. Snižení úmrtí nebo hospitalizace pro zhoršení srdečního selhání a celkové mortality po katetrizační ablaci v porovnání s farmakoterapií u pacientů se srdečním selháním, jehož príčinu je FS (4)

A. Úmrtí nebo hospitalizace z důvodu zhoršení srdečního selhání

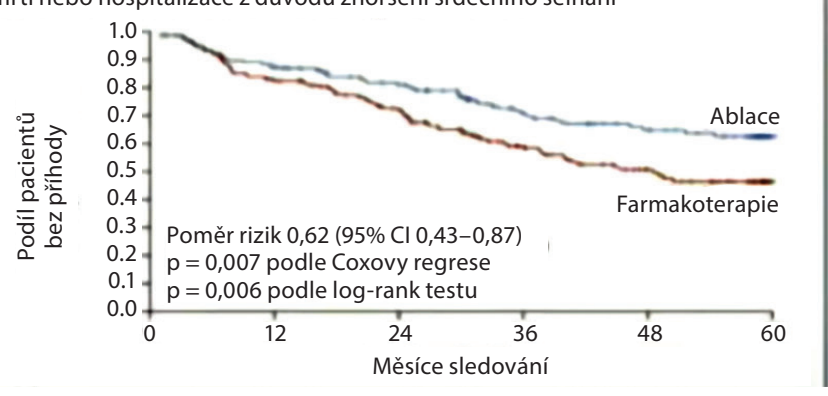

V IKEM probíhá v současné době výzkumný projekt nazvaný HOBIT-FS, který hodnotí vliv komplexní intervence cílené na snížení tělesné hmotnosti na kontrolu rytmu u 160 obézních pacientů po katetrizační ablaci FS. Intervence zahrnuje úpravu stravy a pohybové aktivity, antiobezitika a u některých nemocných i bariatrickou léčbu s cílem snížení tělesné hmotnosti o $\geq 10 \%$ za 18 měsíců. Ke sledování výskytu arytmií a pohybové aktivity se použivají chytré hodinky.

Současná úprava více rizikových faktorů u pacientů s katetrizačni ablací FS zahrnující snižení tělesné hmotnosti, kompenzaci krevního tlaku a glykemie, úpravu dyslipidemie a léčbu spánkové apnoe byla spojena s významně nižším rizikem recidiv FS (12).

Bylo také prokázáno, že riziko vzniku FS narůstá se stoupající konzumací alkoholu a počtem vykouřených cigaret $(13,14)$. Studie provedená
B. Úmrtí z jakékoliv příčiny

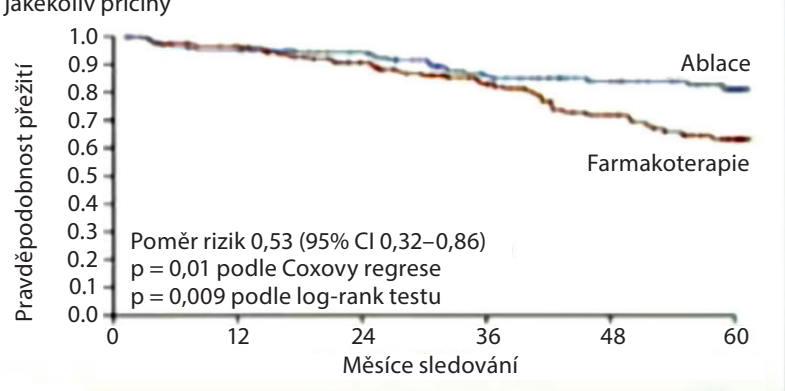

\section{LITERATURA}

9. Kloosterman M, Oldgren J, Conen D, Wong JA, Connolly SJ, Avezum A, Yusuf S, Ezekowitz MD, Wallentin L, Ntep-Gweth M, Joseph P, Barrett TW, Tanosmsup S, Mclntyre WF, Lee SF, Parkash R, Amit G, Grinvalds A, Van Gelder IC, Healey JS. Characteristics and outcomes of atria fibrillation in patients without traditional risk factors: an RE-LY AF registry analysis. Europace. 2020 Jun 1; 22(6): 870-877.

10. Sramko M, Wichterle D, Melenovsky V, Clemens M, Fukunaga M, Peichl P, Aldhoon B, Cihak R Kautzner J. Resting and Exercise-Induced Left Atrial Hypertension in Patients With Atrial Fibrillation: The Causes and Implications for Catheter Ablation. JACC Clin Electrophysiol. 2017 May; 3(5):461-469. 11. Pathak RK, Middeldorp ME, Meredith M, Mehta AB, Mahajan R, Wong CX, Twomey D, Elliott AD, Kalman JM, Abhayaratna WP, Lau DH, Sanders P. Long-Term Effect of Goal-Directed Weight Management in an Atrial Fibrillation Cohort: A Long-Term Follow-Up Study (LEGACY). Am Coll Cardiol 2015; 65(20): 2159-2169.

12. Pathak RK, Middeldorp ME, Lau DH, Mehta AB, Mahajan R, Twomey D, Alasady M, Hanley L, Antic NA, McEvoy RD, Kalman JM, Abhayaratna WP, Sanders P. Aggressive risk factor reduction study for atrial fibrillation and implications for the outcome of ablation: the ARREST-AF cohort study. J Am Coll Cardiol 2014; 64(21): 2222-2231.

13. Voskoboinik A, Prabhu S, Ling LH, Kalman JM, Kistler PM. Alcohol and Atrial Fibrillation: A Sobering Review. J Am Coll Cardiol. 2016; 68(23): 2567-2576.

14. Aune D, Schlesinger S, Norat T, Riboli E. Tobacco smoking and the risk of atrial fibrillation: A systematic review and meta-analysis of prospective studies. Eur J Prev Cardiol 2018; 25(13): 1437-1451. 15. Khan H, Kella D, Rauramaa R, Savonen K, Lloyd MS, Laukkanen JA. Cardiorespiratory fitness and atrial fibrillation: A population-based follow-up study. Heart Rhythm 2015; 12(7): 1424-1430

\section{Fibrilace síní u pacientů se srdeční resynchronizační léčbou: Jak postupovat? MUDr. Robert Čihák, CSc. (Klinika kardiologie IKEM, Praha)}

Srdeční resynchronizační léčba (CRT) v indikovaných prípadech zlepšuje morbiditu i mortalitu pacientů se srdečním selháním, dysfunkcí levé komory a blokádou levého Tawarova raménka. Cílem této léčby je 100\%

u pacientů s ischemickou chorobou srdeční (ICHS) také ukázala, že s rizikem FS souvisí míra fyzické zdatnosti. Nejnižší riziko bylo pozorováno u pacientů ve 3. kvartilu kardiorespirační fyzické zdatnosti (dle metabolických jednotek, MET) (15). Již malé zvýšení fyzické aktivity se zlepšením fyzické zdatnosti o $\geq 2$ MET bylo spojeno s nižším rizikem recidivy FS (11).

\section{Závěr}

FS je multifaktoriální onemocnění. Významné ovlivnitelné rizikové faktory zahrnují obezitu, konzumaci alkoholu, kouření a nedostatek fyzické aktivity. Bylo prokázáno, že úprava životního stylu je spojena s větší pravděpodobností udržení sinusového rytmu, a tím i se zlepšením prognózy pacientů. Na druhou stranu je výskyt FS určitým markerem př́tomnosti kardiovaskulárního rizika nebo onemocnění a měl by vést k podrobnému vyšetření postižených jedinců.

uplatnění stimulace. Výskyt FS s nepravidelnou a vlastní (nestimulovanou) akcí komor brání obvykle dosažení 100 \% biventrikulární stimulace. Příkladem postupu dosažení pravidelné biventrikulární stimulace u pacientů se srdečním selháním a FS s rychlou odpovědí komor je kombinace implantace biventrikulárního defibrilátoru a ablace atrioventrikulárního (AV) uzlu. Dosud největší metaanalýza studií s CRT pokrývající 31 studií s 83571 účastníky se srdečním selháním zahrnovala 36\% pacientů s FS. Mortalita pacientů s FS byla v porovnání s pacienty se sinusovým rytmem o 47\% vyšší (16). Provedení ablace AV junkce u těchto nemocných podle uvedené metaanalýzy významně sníži mortalitu. Ta se dokonce blíží mortalitě pacientů se sinusovým rytmem. Nedávno publikovaná metatanalýza 14 studií s celkem 3199 pacienty porovnávala CRT stimulaci s ablací AV junkce a samotnou CRT stimulaci u pacientů se srdečním selháním a permanentní FS. Ve skupině s ablací AV uzlu bylo častěji dosaženo biventrikulární stimulace, zlepšení ejekční frakce levé komory a snížení průměru levé komory na konci diastoly. $V$ souvislosti s tím bylo u pacientů s kombinovanou léčbou pozorováno snížení celkové mortality, KV mortality i opakovaných hospitalizací pro srdeční selhání (17). Ablace AV junkce zlepšuje u těchto pacientů také toleranci zátěže a kvalitu života.

Nevýhody ablace AV junkce zahrnují zvýšení závislosti na stimulaci (možný problém při poruše prístroje nebo nutnosti explantace) a možnost suboptimálního výsledku při nevhodném umístění elektrod.

V České republice bylo v roce 2020 provedeno 374 ablací AV uzlu. Nejvíce těchto zákroků se uskutečnilo na pracovišti IKEM, kde ablace AV uzlu provázela zhruba 40\% implantací CRT, v porovnání s 10-15\% na 


\section{| NOVINKY V KARDIOLOGII}

NOVÉ POHLEDY NA LÉČBU ARYTMIÍ

ostatních českých pracovištích. Jedno vysvětlení spočívá v tom, že v IKEM se koncentrují pacienti s velmi pokročilým srdečním selháním. Druhé možné vysvětlení připouští možnost, že v jiných centrech nejsou pacienti indikováni k optimalizaci CRT pomocí ablace AV uzlu.

Jako alternativa CRT se v poslední době rozšiřuje stimulace převodního systému (Hisova svazku, levého raménka). Také při stimulaci Hisova svazku Ize provést ablaci AV uzlu.

Ablace AV uzlu se provádí rovněž bez CRT. Jedná se o pacienty se zachovanou funkcí levé komory, kdy se implantuje jen pravokomorová elektroda, a o pacienty s FS, u nichž již není ablace indikována pro FS. $\checkmark$ rámci $A B C$ př́stupu podle oficiálních doporučení pro léčbu všech pacientů s FS znamená písmeno B lepší kontrolu obtízí, kam spadá kontrola srdečního rytmu a srdeční frekvence (19).

U některých pacientů je FS pravděpodobně príčinou vzniku nebo zhoršení srdečního selhání. Katetrizační ablace dokáže u těchto pacientů v porovnání s farmakoterapií podle výsledků již zmíněné studie CASTLE snízit celkovou mortalitu a riziko úmrtí nebo hospitalizace z důvodu srdečního selhání (4). Tento postup je vhodný především u pacientů s přechodnou dysfunkcí levé komory, u nichž se po obnově sinusového rytmu funkce levé komory zlepšuje. Výraznější efekt katetrizační ablace pro

\section{LITERATURA}

16. Mustafa U, Atkins J, Mina G, Dawson D, Vanchiere C, Duddyala N, Jones R, Reddy P, Dominic P. Outcomes of cardiac resynchronisation therapy in patients with heart failure with atrial fibrillation: a systematic review and meta-analysis of observational studies. Open Heart 2019; 6(1): e000937.

17. Waranugraha Y, Rizal A, Setiawan D, Aziz IJ. The Benefit of Atrioventricular Junction Ablation for Permanent Atrial Fibrillation and Heart Failure Patients Receiving Cardiac Resynchronization Therapy: An Updated Systematic Review and Meta-analysis. Indian Pacing Electrophysiol J 2021; 21(2): 101-111.

18. Muthumala A, Vijayaraman P. His-Purkinje conduction system pacing and atrioventricular node ablation. Herzschrittmacherther Elektrophysiol. 2020; 31(2): 117-123.

19. Hindricks G, Potpara T, Dagres N, Arbelo E, Bax JJ, Blomström-Lundqvist C, Boriani G, Castella M, Dan GA, Dilaveris PE, Fauchier L, Filippatos G, Kalman JM, La Meir M, Lane DA, Lebeau JP, Lettino M, Lip GYH, Pinto FJ, Thomas GN, Valgimigli M, Van Gelder IC, Van Putte BP, Watkins CL; ESC Scientific Document Group. 2020 ESC Guidelines for the diagnosis and management of atrial fibrillation developed in collaboration with the European Association for Cardio-Thoracic Surgery (EACTS): The Task Force for the diagnosis and management of atrial fibrillation of the European Society of Cardiology (ESC) Developed with the special contribution of the European Heart Rhythm Association (EHRA) of the ESC. Eur Heart J. 2021; 42(5): 373-498. 20. Jodko Ł, Kornacewicz-Jach Z, Kaźmierczak J, Rzeuski R, Zielonka J, Kaliszczak R, Safranow K. Inappropriate cardioverter-defibrillator discharge continues to be a major problem in clinical practice. Cardiol J 2009; 16(5): 432-439.

\section{Jak postupovat u elektrické bouře? doc. MUDr. Petr Peichl, Ph.D. (Klinika kardiologie IKEM, Praha)}

Elektrická bouře je definována jako stav, charakterizovaný výskytem z 3 epizod významných komorových tachyarytmií (KT) během 24 hodin, mezi nimiž je interval alespoň 5 minut. $\vee$ patofyziologii arytmií se uplatňuje tzv. trojúhelník arytmogeneze, který definoval P. Coumel. Zahrnuje arytmogenní substrát (např. jizva po infarktu myokardu), vyvolávající faktor (např. spouštěcí extrasystola) a modulující faktory (autonomní nervový systém, ischemie, hypokalemie). Při snaze ovlivnit elektrickou bouři je třeba cílit na všechny tyto faktory.

Ve farmakoterapii elektrické bouře se stále uplatňuji $\beta$-blokátory a amiodaron. Nedávná studie ukázala, že neselektivní $\beta$-blokátory by moh-
FS u pacientů se srdečním selháním v porovnání s pacienty bez srdečního selhání potvrdila i analýza podskupin ze studie CABANA (5).

Neadekvátní výboje u pacientů s implantovaným defibrilátorem (ICD), kteří mají FS s rychlou odpovědí komor, výrazně zhoršují kvalitu jejich života i prognózu. U 190 pacientů s ICD a FS sledovaných 34 měsícủ bylo chybně rozpoznáno 19,2\% př́hod, které vedly k neoprávněným výbojům ICD. Nejčastějším důvodem těchto neoprávněných výbojů (42,2\%) byly FS/flutter síní (20). V prípadě oprávněných výbojů tyto pacienty léčíme antiarytmickou medikací nebo provádíme ablaci pro komorové tachykardie a v prípadě neoprávněných výbojů Ize situaci řešit farmakologickou kontrolou srdeční frekvence a rytmu nebo ablací FS či ablací AV junkce.

\section{Závěr}

U části pacientů je srdeční selhání důsledkem FS. U nich je vhodné zvážit ablaci pro FS. Pokud je FS nově zjištěna u pacientů s CRT, Ize také zvážit nejprve ablaci pro FS. Při CRT stimulaci a FS, kdy nezvažujeme selektivní ablaci FS, je u většiny pacientů indikována ablace AV junkce. V ČR je tento postup uplatňován méně často, než by odpovídalo počtu implantací CRT přístrojů. Na podporu časné AV uzlu ukazuje i výskyt neadekvátních výbojů u pacientů s ICD a FS, které zhoršují kvalitu jejich života i prognózu.

ly být v této situaci prínosnější než selektivní $\beta$-blokátory. Randomizovaná studie se 60 pacienty s ICD a arytmickou bouři ukázala 2,7krát nižší výskyt KT, rychlejší vymizení arytmií a kratší dobu hospitalizace při léčbě metoprololem + amiodaronem v porovnání s propranololem + amiodaronem (21). U elektrické bouře existují i zvláštní situace vyžadující jinou léčbu. Jde o syndrom Brugadových, u něhož se podává isoproterenol + chinidin, syndrom dlouhého intervalu QT, kde se nepodává amiodaron, ale využívá se odstranění spouštěcích faktorů, $\beta$-blokátory, popř. sympatektomie, syndrom krátkého intervalu QT, u něhož se podává chinidin, a katecholaminergní polymorfní KT, kdy je vedle $\beta$-blokátorů a sedace lékem volby flekainid.

$\checkmark$ léčbě elektrické bouře se již dlouho použivá sedace. Důkazy o přínosu tohoto postupu přinesla teprve nedávno francouzská práce, v ní̌ u 116 pacientů ze 13 center vedl tento postup ve 47\% k ukončení arytmické bouře do 15 minut, což bylo spojeno s 55\% snížením mortality (22). U 33\% pacientů ovšem došlo k pneumonii/aspiraci. Prediktorem absence odpovědi na léčbu byl plicní edém. Jiný způsob, jak ovlivnit autonomní nervový systém, je opich ganglion stellatum. Jedná se o aplikaci $7 \mathrm{ml}$ bupivacainu pod ultrasonografickou kontrolou. Zákrok Ize provést u lůžka a je spojen malým rizikem komplikací. Prokázáno bylo akutní snižení četnosti epizod KT až o 92\% během 72 hodin. Efekt přetrvává zhruba týden a slouží ke stabilizaci stavu před trvalým řešením, např. katetrizační ablací.

Katetrizační ablace je velice účinná metoda, která cílí na anatomický substrát, např. jizvu po infarktu myokardu, tedy místo vzniku okruhů re-entry, které jsou podkladem komorových arytmií. Pomocí trojrozměrných mapovacích systémů můžeme zmapovat kanály pomalého vedení a ošetřit je tak, abychom minimalizovali riziko recidiv KT. Ne všechny KT vznikají na podkladě anatomického substrátu, v některých případech se může jednat o funkční substrát. V takovém prípadě může katetrizační ablace cílit na spouštěcí mechanismus (extrasystolu) nebo funkční kom- 
Obr. 4. Vliv elektrické bouře na mortalitu (A) a vliv indukovatelnosti komorové tachyartymie (KT) po katetrizačni ablaci na mortalitu (B) u pacientů s KT (23)

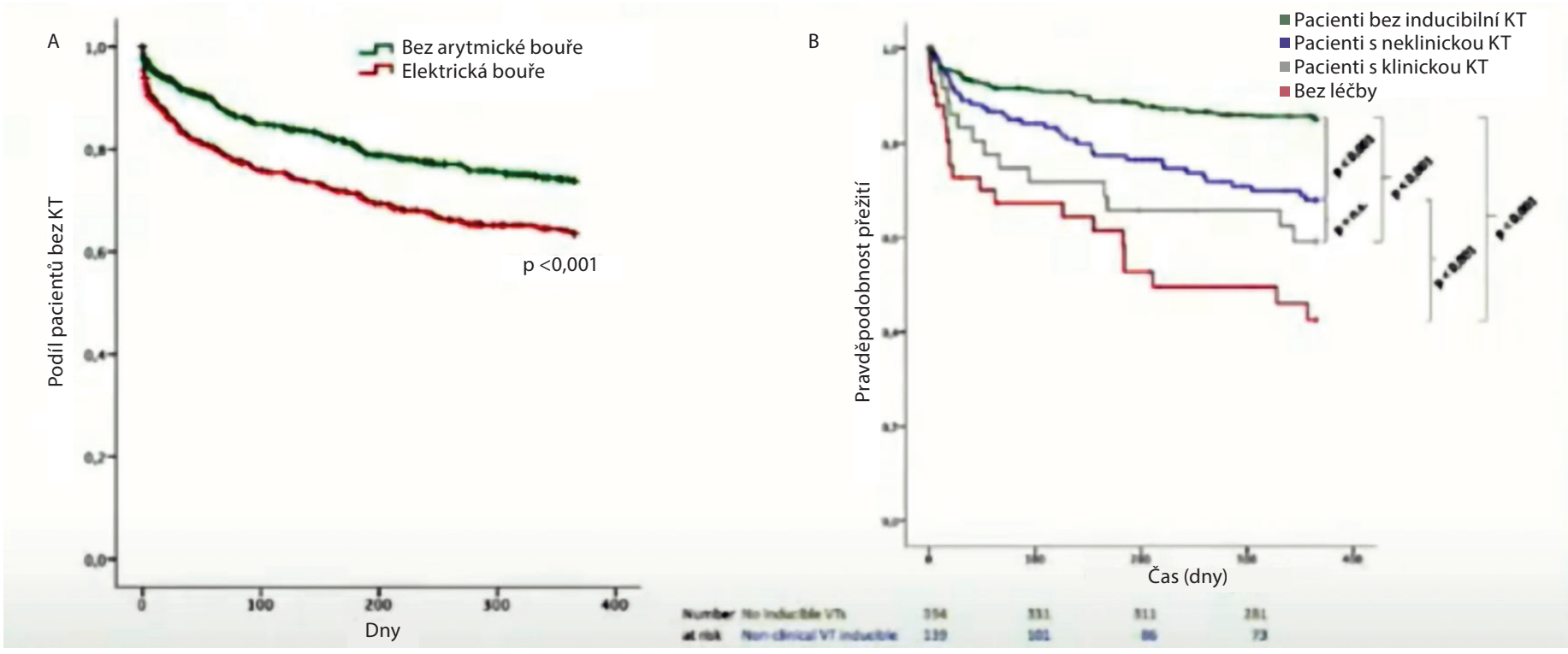

ponentu okruhu. Katetrizační ablace je v léčbě arytmické bouře velmi účinná a výrazně zlepšuje prognózu pacientů. Studie zahrnující 1940 pacientů, kteři podstoupili katetrizační ablaci pro KT, zahrnovala $34 \%$ pacientů s arytmickou bouří. Pacienti s bouří měli více indukovatelných artymií, větší mortalitu za hospitalizace (6,2 vs. 1,4\%) a horší prognózu. Pokud ale katetrizační ablace účinně ovlivní substrát a je dosaženo neindukovatelnosti klinické komorové tachyarytmie, je mortalita účinně snížena (obr. 4) (23).Po 1 roce bylo naživu 86,3\% pacientů bez indukovatelné KT na konci zákroku, 72,9\% pacientů s neklinickou KT a 51,2\% pacientů s klinickou KT.

U souboru 93 pacientů s katetrizační ablací provedenou při arytmické bouři na pracovišti IKEM v letech 2006-2013 identifikovali autoři 5 prediktorů mortality. Zahrnují věk nad 70 let, NYHA třídu $\geq 3$, sérovou hladinu kreatinu $\geq 115 \mu \mathrm{mol} / \mathrm{l}$, ejekční frakci levé komory $\leq 25 \%$ a léčbu amiodaronem. U některých pacientů na hranici mezi arytmií a srdečním selháním Ize využít hemodynamickou podporu bud’ ke stabilizaci stavu nebo jako podporu při ablaci.

\section{LITERATURA}

21. Chatzidou S, Kontogiannis C, Tsilimigras DI, Georgiopoulos G, Kosmopoulos M, Papadopoulou E, Vasilopoulos G, Rokas S. Propranolol Versus Metoprolol for Treatment of Electrical Storm in Patients With Implantable Cardioverter-Defibrillator. J Am Coll Cardiol 2018; 71(17): 1897-1906. 22. Martins RP, Urien JM, Barbarot N, Rieul G, Sellal JM, Borella L, Clementy N, Bisson A, Guenancia C, Sagnard A, Schumacher S, Gandjbakhch E, Duchateau J, Tixier R, Goepp A, Hamon D, Lellouche N, Champ-Rigot L, Milliez P, Marijon E, Varlet E, Garcia R, Degand B, Bouju P Mabo P, Leclercq C, Behar N, Pavin D, de Chillou C, Sacher F, Galand V. Effectiveness of Deep Sedation for Patients With Intractable Electrical Storm Refractory to Antiarrhythmic Drugs. Circulation 2020; 142(16): 1599-1601.

23. Vergara $P$, Tung R, Vaseghi M, Brombin C, Frankel DS, Di Biase L, Nagashima K, Tedrow $U$ Tzou WS, Sauer WH, Mathuria N, Nakahara S, Vakil K, Tholakanahalli V, Bunch TJ, Weiss JP, Dickfeld T, Vunnam R, Lakireddy D, Burkhardt JD, Correra A, Santangeli P, Callans D, Natale A Marchlinski F, Stevenson WG, Shivkumar K, Della Bella P. Successful ventricular tachycardia ablation in patients with electrical storm reduces recurrences and improves survival. Heart Rhythm 2018; 15(1): 48-55.

24. Aldhoon B, Wichterle D, Peichl P, Čihák R, Kautzner J. Outcomes of ventricular tachycardia ablation in patients with structural heart disease: The impact of electrical storm. PLoS One 2017; 12(2): e0171830
Řešení elektrické bouře musí být komplexní, zahrnuje řadu postupů a kroků ke stabilizaci pacienta. Léčba by měla probíhat v komplexním kardiocentru a vyžaduje multidisciplinární prístup. Je třeba posoudit reverzibilní př́činy a stratifikovat nemocné s KT bez reverzibilní př́činy. U hemodynamicky stabilních pacientů s nečetnými KT se provádí elektivní ablace během hospitalizace, v případě incesantních KT nebo arytmické boure je na místě časná ablace, u hemodynamicky nestabilních pacientů se srdečním selháním je prioritou léčba srdečního selhání.

\section{Závěr}

Elektrická bouře je závažný, život ohrožující stav, který výrazně zhoršuje prognózu pacientů. Z farmakoterapie je nejvhodnější kombinace ß-blokátoru, lépe neselektivního, a amiodaronu, u primárních arytmických syndromů pak specifická antiarytmická léčba. Pro akutní potlačení bouře je účinná sedace, př́padně blokáda ganglion stellatum. Účinnou metodou pro potlačení arytmické bouře a prevenci recidiv arytmií je katetrizační ablace. Je třeba ji ale indikovat včas a referovat pacienta do specializovaného centra.

\section{Katetrizační ablace místo kardiostimulátoru? doc. MUDr. Dan Wichterle, Ph.D. (Klinika kardiologie IKEM, Praha)}

Kardioneuroablace je katetrizační procedura, která se snaží potlačit nadměrnou parasympatickou modulaci sinoatriálního a atrioventrikulárního uzlu, a tím zabránit epizodickým či setrvalejším bradyarytmiím. Kardioneuroablace znamená změnu v paradigmatu katetrizačních ablací. Zatímco klasická ablace cilí na myokard nebo převodní systém a jejím cílem je prímá suprese patologického substrátu (odstranění, přerušení, blok, izolace), kardioneuroablace cílená na srdeční intrinsický autonomní nervový systém vede k supresi negativní chronotropie či negativní dromotropie s výsledným pozitivním funkčním efektem. 


\section{NOVINKY V KARDIOLOGII}

NOVÉ POHLEDY NA LÉČBU ARYTMIÍ

Obr. 5. Výsledky kardiostimulace (A) a kardioneuroablace (B) v léčbě neurokardiogenních synkop (27, databáze IKEM)

Studie BioSync CLS

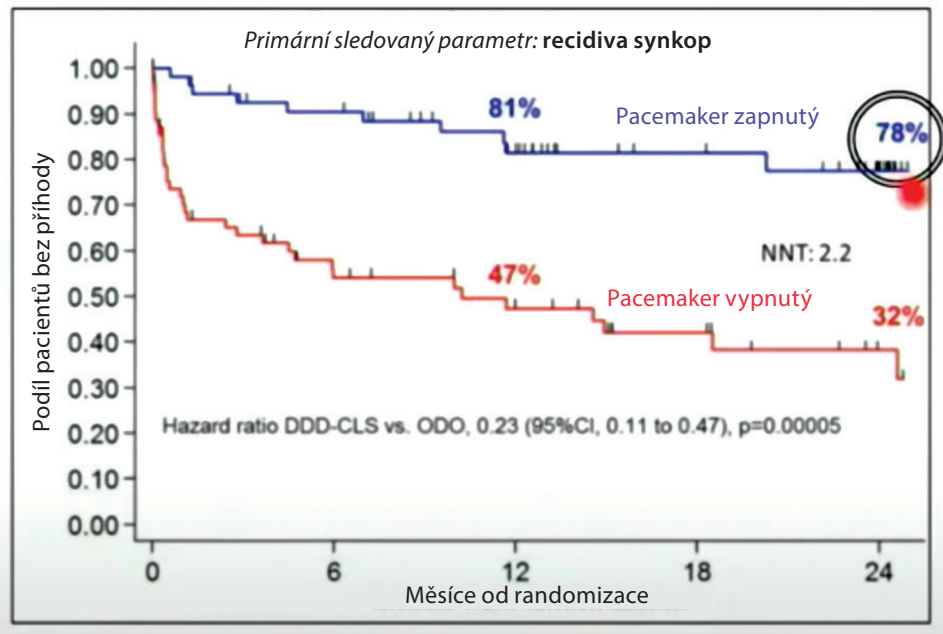

Kardioneuroablace IK

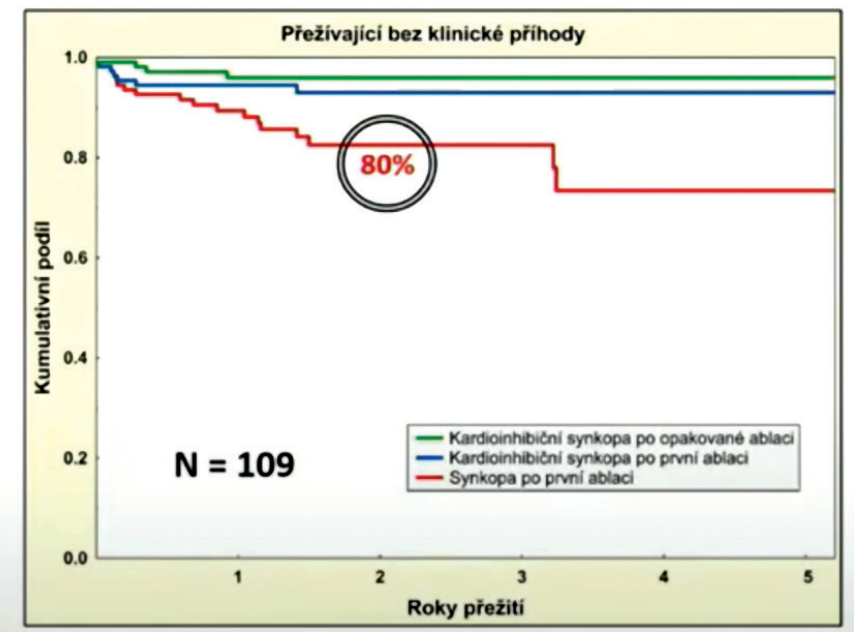

Léčba kardioneuroablací je vhodná u pacientů s recidivujícími neurokardiogenními (vasovagálními) synkopami, které mají kardioinhibiční složku, a také u pacientů se symptomatickou sinusovou bradykardií nebo epizodickou AV blokádou, které mají alespoň z části funkční etiologii. Pacienti musejí vykazovat rezistenci na běžnou léčbu a mít fyziologický výsledek atropinového testu (dostatečná akcelerace sinusového rytmu nebo vymizení AV blokády po i.v. aplikaci 2 mg atropinu).

Faktory spojené s úspěšnou kardioneuroablací zahrnují nižší věk, absenci průvodních onemocnění, zjištěný spouštěč (např. situační synkopy - polykací, mikční aj.) a EKG fenotyp kardioinhibice, který svědčí pro vagovou hyperaktivitu.

Doporučené postupy Evropské kardiologické společnosti pro léčbu synkop z roku 2018 zmiňují kardioneuroablaci jen okrajově s tím, že se zatím jedná o nedostatečně prověřenou léčbu (25). Naopak doporučují kardiostimulaci na základě dat z několika relativně malých randomizovaných studií, ve kterých trvalá kardiostimulace prokázala pouze snižení, nikoliv úplné vymizení synkop a přinesla důkazy pouze pro pacienty starší 40 let s průměrným věkem kolem 60 let (26)

Kardioneuroablace je v našem podání anatomicky navigovaný výkon, který se provádí v celkové anestezii. Využívá se elektroanatomické mapo- vání a intrakardiální ultrasonografické zobrazení. Ablace je vždy biatriální. K posouzení efektu ablace se využívá extrakardiální oboustranné stimulace nervus vagus jako manévru ověřujícího postupné dosažení denervace během kladení ablačních lézí. Cílem je kompletní denervace sinoatriálního i AV uzlu a současná minimalizace počtu ablačních lézí.

V IKEM se kardioneuroablace provádí od roku 2014. Do konce roku 2020 ji podstoupilo 109 pacientů a výsledky jsou znázorněny na obr. 5B. Klinické výsledky kardioneuroablace jsou zcela srovnatelné s výsledky nedávno publikované studie, ve které byla použita nejmodernější technologie kardiostimulace pro prevenci kardioinhibičních synkop (obr. 5A) (27).Valná většina recidiv synkop po kardioneuroablaci má čistě vasodepresorický mechanismus.

\section{Závěr}

Kardioneuroablace je perspektivní léčebná metoda u mladších pacientů s funkčními poruchami na podkladě nadměrné vagové modulace srdečního rytmu - s reflexními kardioinhibičními synkopami nebo jinými symptomatickými bradyarytmiemi. Jde o bezpečnou metodu s jasným procedurálním cílem, která má vysokou klinickou účinnost. Představuje alternativu implantace pacemakeru.

Pripravila MUDr. Zuzana Zafarová

(ISSUE-3) Investigators. Pacemaker therapy in patients with neurally mediated syncope and documented asystole: Third International Study on Syncope of Uncertain Etiology (ISSUE-3): a randomized trial. Circulation 2012; 125(21): 2566-2571

27. Brignole M, Russo V, Arabia F, Oliveira M, Pedrote A, Aerts A, Rapacciuolo A, Boveda S, Deharo JC, Maglia G, Nigro G, Giacopelli D, Gargaro A, Tomaino M; BioSync CLS trial Investigators. Cardiac pacing in severe recurrent reflex syncope and tilt-induced asystole. Eur Heart J 2021;42(5): 508-516. 